\title{
Peranan Gaya Kepemimpinan dan Pengambilan Keputusan dalam Upaya Meningkatkan Prestasi Kerja di PT. DJARUM
}

\author{
WAHYU NUR ROMADON \\ wahyunurromadon@gmail.com \\ Mahasiswa Fakultas Ekonomi dan Bisnis Universitas Narotama
}

\begin{abstract}
ABSTRAK
Tujuan dari studi ini adalah untuk mengetahui fungsi dan tujuan pengambilan keputusan dan mengetahui proses dan cara mengevaluasi kinerja karyawan. Dalam penelitian ini digunakan pendekatan kualitatif, dalam penelitian kualitatif, peneliti sekaligus berfungsi sebagai instrument utama yang terjun kelapangan serta berusaha sendiri mengumpulkan data melalui observasi maupun wawancara dan interview. Dalam penelitian ini digunakan metode induktif untuk menarik suatu kesimpulan terhadap hal-hal atau peristiwa-peristiwa dari data yang telah dikumpulkan melalui observasi, wawancara, dan dokumentasi, yang bisa digeneralisasikan (ditarik kearah kesimpulan umum), maka jelas metode induktif ini untuk menilai fakta-fakta empiris yang ditemukan lalu dicocokan dengan teori-teori yang ada. Pengambilan keputusan yang efektif dapat berpengaruh terhadap peningkatan kualitas kinerja perusahaan yang dalam implementasinya bisa melalui variabel perantara yaitu meningkatnya kinerja, semangat, kreativitas dari karyawan-karyawan yang dipimpinnya.
\end{abstract}

Kata Kunci ; Pengambilan Keputusan, Metode Induktif, kinerja karyawan

\section{PENDAHULUAN}

\subsection{Latar Belakang}

Pengambilan keputusan merupakan tindakan manajemen dalam mencapai sasaran. Teori pengambilan keputusan memiliki unsur-unsur utama berupa pembuat keputusan dihadapkan pada suatu masalah tertentu yang dapat diperbandingkan satu sama lain, Tujuan-tujuan, nilai-nilai atau sasaran yang mempedomani pembuat keputusan amat jelas dan dapat ditetapkan tingkatannya sesuai dengan urutan pentingnya. Berbagai alternatif untuk memecahkan masalah tersebut diteliti secara seksama. Akibatakibat yang ditimbulkan oleh setiap alternatif yang dipilih dengan teliti. Setiap alternatif dan masingmasing akibat yang menyertainya dapat dibandingkan dengan alternatifalternatif lainnya serta pembuat keputusan akan memilih alternatif dan akibat-akibatnya yang dapat memungkinkan tercapainya tujuan, nilai atau sasaran. Dengan banyaknya alternatif yang mempengaruhi sebuah keputusan maka sulit untuk mengambil sebuah keputusan secara manual.

\subsection{Rumusan Masalah}

1. Bagaimana fungsi dan tujuan pengambilan keputusan pada pt. djarum ?

2. Bagaimana cara Manager mengevaluasi kinerja karyawan di pt.djarum ?

3. Bagaimana Proses pengambilan keputusan?

\subsection{Tujuan}

1. Mengetahui fungsi dan tujuan pengambilan keputusan.

2. Mengetahui cara mengevaluasi kinerja karyawan.

3. Mengetahui proses pengambilan keputusan. 


\section{TINJAUAN PUSTAKA}

Dalam kehidupan sehari-hari kita selalu dihadapkan dengan istilah organisasi

Organisasi bisnis biasanya bertujuan untuk mencari keuntungan finansial, organisasi kemasyarakatan biasanya bertujuan untuk tujuan kemasyarakatan, organisasi politik biasanya untuk tujuan kekuasaan dan organisasi keagamaan biasanya untuk tujuan misi atau dakwah.Tujuan tersebut menurut AsakuWalisongo (2013) dicerminkan oleh sasaran yang harus dilakukan baik dalam jangka pendek, maupun jangka panjang.Implementasinya setiap organisasi merumuskan visi, misi, serta tujuan baik jangka pendek, menengah maupun jangka panjang.

Setiap organisasi tentu memiliki pemimpin dan kepemimpinan.Biasanya pemimpin memiliki pengaruh lebih besar dalam upaya pencapaian tujuan organisasi, oleh karena pemimpin sering diistilahkan dengan orang yang mempengaruhi bawahan untuk mencapai tujuan yang diharapakan. Pendapat itu sejalan dengan yang disampaikan olehHusaini Usman (2013 : 312), kepemimpinan ialah ilmu dan seni mempengaruhi, orang atau kelompok untuk bertindak seperti yang diharapkan untuk mencapai tujuan secara efektif dan efisien. Jadi jelas bahwa pemimpin memiliki pengaruh besar terhadap sukses tidaknya sebuah oraganisasi.

Salah satu fungsi yang harus dilakukan pemimpin dalam upaya pencapaian tujuan adalah bagaimana pemimpin itu bisa mengambil keputusan dengan efektif.Dalam realita pengambilan keputusan bukanlah hal yang sedernana, sebab setiap pengambilan keputusan biasanya mengandung dua konsekuensi sekaligus baik konsekuensi positif maupun konsekuensi negatif. Namun demikian seorang pemimpin harus berani mengambil keputusan dari beberapa pilihan yang dihadapai.

Seorang pemimpin diharapkan mengikuti pendapat Terry dalam Marzuki (2015 : 2), bahwa dalam mengambil keputusan hendaklah memilih yang terbaik dari berbagai altenatif yang tersedia. Salah satu tugas terpenting seorang pemimpin adalah untuk menentukan yang terbaik bagi organisasi dan para anggotanya.Namun dalam mengambil keputusan, terkadang pemimpin pun menghadapi dilema dan seolah berada di persimpangan jalan.

Kecepatan dan ketepatan seorang pemimpin dalam mengambil keputusan lazimnya menjadi tolak ukur kompetensi dan kredibilitas yang dimilikinya. Jika pemimpin lamban dan raguragu dalam bertindak, anak buah akan melihat bahwa pemimpin tersebut adalah pemimpin yang tidak berani mengambil resiko. Terbiasa cepat dalam pengambilan keputusan memang bukan pekerjaan mudah, butuh rasio yang jernih dan intuisi yang tajam agar bisa menghasilkan keputusan yang tepat.Menarik untuk dikaji bagaimana seorang pemimpin bisa mengambil keputusan dengan baik, dalam pengertian efektif, efisien, meminimalkan resiko, serta bermanfaat bagi kemajuan organisasi dalam rangka pencapaian tujuan yang diharapkan.

\section{Pengertian Pengambilan Keputusan}

Drommond (1985) berpendapat bahwa pengambilan keputusan merupakan usaha penciptaan kejadian-kejadian dan pembentukan masa depan (peristiwa-peristiwa pada saat pemilihan dan sesudahnya). Pendapat ini menegaskan bahwa pengambilan keputusan merupakan proses pada saat sejumlah langkah yang harus dilakukan dengan pengevaluasian alternatif untuk membuat putusan dari semua alternatif yang ada (Syaruddin:48).

dari beberapa definisi dijelaskan di atas, maka disimpulkan bahwa pengambilan keputusan adalah proses pemecahan masalah dengan menentukan pilihan dari beberapa alternatif untuk menetapkan suatu tindakan yang ingin dilakukan dalam mencapai tujuan yang diinginkan. 
Pengambilan keputusan dengan kreatif dan inovatif.

Pengambilan keputusan dengan tidak kreatif mempunyai kecenderungan untuk membuat keputusan secara emosional. Dengan menggunakan kreativitasnya, pengambilan keputusan dapat menemukan alternatif-alternatif untuk memecahkan masalah, kemudian memilih salah satu alternatif yang bermanfaat bagi pencapaian organisasi. Inovasi memungkinkan pengambilan keputusan melaksanakan keputusan dengan baik.

Berdasarkan jenis problemnya dikelompokkan menjadi:

Pengambilan keputusan terprogram, yaitu pembuatan keputusan dapat dilakukan dengan menggunakan standar prosedur operasi rutin. Cirinya adalah:

Problemnya terstruktur, sederhana dan informasinya tersedia lengkap.

Problem dan proses pembuatan keputusannya sudah berulang-ulang terjadi sehingga sudah dapat diperhitungkan dan mempunyai pengalaman menyelesaikannya.

Pengambilan keputusan tidak terprogram ialah pengambilan keputusan yang problemnya unik, belum pernah terjadi. Informasi mengenai problem belum tersedia atau sedikit,peraturan, kebijakan, prosedur operasi standar untuk membuat keputusan yang belum ada. (Wirawan, 2014:556).

\section{METODE PENELITIAN}

Dalam kaitan ini Arief Furchan (1999: 22) menerangkan sebagai berikut:

Metode kualitatif ialah "proses penelitian yang menghasilkan data deskriftif, ucapan atau tulisan atau perilaku yang dapat diamati dari orang-orang itu sendiri, menurut pendapat kami pendekatan ini langsung menunjukan setting dan individu-individu dalam setting itu secara keseluruhan. Subyek penyelidikan baik berupa organisasi atau individu tidak mempersempit menjadi variable yang terpisah atau menjadi hipotesa melainkan dipandang sebagai suatu keseluruhan. Dari pendapat diatas, dapat dikatakan bahwa pendekatan kualitatif berusaha mendapatkan data deskriptif, ucapan atau tulisan dan perilaku yang dapat diamati.

Dalam penelitian ini digunakan pendekatan kualitatif dengan alasan mengacu pada beberapa alasan sebagai mana yang dikemukakan oleh. Margono (2000: 37) antara lain:

1. Untuk menanggulangi banyaknya informasi yang hilang, seperti yang dialami oleh penelitian kualitatif sehingga intisari konsep yang ada pada data dapat diungkap.

2. Untuk menaggulangi kecenderungan menggali data empiris dengan tujuan membuktikan kebenaran hipotesis akibat dari adanya hipotesis yang disusun sebelumnya berdasarkan berfikir deduktif seperti dalam pemikiran kuantitatif.

3. Untuk menanggulangi kecenderungan pembatasan variable yang sebelumnya, seperti dalam penelitian kuantitatif padahal permasalahan dan variable dalam masalah social sangat kompleks.

4. Untuk menanggulangi adanya indeks-indeks kasar seperti dalam penelitian kuantitatif yang menggunakan pengukuran enumerasi (perhitungan) empiris, padahal inti sebenarnya berada pada konsep-konsep yang timbul dari data.

Disamping alasan diatas, dalam peneitian ini digunakan pendekatan kualitatif disebabkan beberapa hal yang cukup penting antara lain: pertama, karena latar belakang penelitian tidak bersifat homogen, kedua, karena penelitian ini ingin mengungkap data dengan apa adanya sesuai dengan hasil temuan dilapangan tentang kepemimpinan manager di pt. djarum 
Kehadiran Peneliti - Metode Penelitian

Untuk mendapatkan data-data yang valid dan obyektif tehadap apa yang diteliti maka kehadiran peneliti dilapangan dalam penelitian kualitatif mutlak diperlukan. Kehadiran peneliti sebagai pengamat langsung terhadap kegiatan-kegiatan yang akan diteliti sangat menentukan hasil penelitian, maka dengan cara riset lapangan sebagai pengamat penuh secara langsung pada lokasi penelitian peneliti dapat menemukan dan mengumpulkan data secara langsung. Jadi dalam penelitian ini, insrtumen penelitian adalah peneliti sendiri yang sekaligus sebagai pengumpul data. Sedangkan instrument-instrumen yang lain merupakan instrument pendukung atau instrumen pelengkap oleh karena itu kehadiran peneliti dilapangan sangatlah diperlukan

Adapun tujuan kehadiran peneliti dilapangan adalah untuk mengamati secara langsung keadaan-keadaan atau kegiatan-kegiatan yang berlangsung, fenomena-fenomena social dan gejala-gejala fsikis yang terjadi di pt. djarum

. Hal tersebut dimaksudkan untuk mengamati langsung apakah kejadian-kejadian tersebut akan berbeda jauh atau relevan dengan hasil-hasil penelitian yang diperoleh dari hasil wawancara.

Prosedur Pengumpulan Data

Dalam penelitian kualitatif, peneliti sekaligus berfungsi sebagai instrument utama yang terjun kelapangan serta berusaha sendiri mengumpulkan data melalui observasi maupun wawancara dan interview secara lebih rinci teknik pengumpulan data yang dipergunakan dalam penelitian ini adalah:

1. Metode Observasi (Pengamatan).

Pengamatan adalah alat pengumpulan data yang dilakukan dengan cara mengamati dan mencatat secara sistimatik gejala-gejala yang diselidiki. (Supardi, 2006: 88). Senada dengan itu Yehoda dkk, (2006: 89) menjelaskan pengamatan akan menjadi alat pengumpulan data yang baik apabila:

a) Mengabdi pada tujuan penelitian

b) Direncanakan secara sistematik

c) Dicatat dan dihubungkan dengan proposisi-prosposisi yang umum

d) Dapat dicetak dan dikontrol validitas, relibilitas, dan ketelitianya.

2. Metode Interview

Metode ini disebut juga dengan metode wawancara, yaitu suatu metode pengumpulan data yang dilakukan melalui Tanya jawab secara langsung dengan sumber data.

Sehungan dengan hal ini Margono (2003: 165) mengemukakan bahwa: "interview merupakan alat pengumpulan informasi dengan cara mengajukan pertanyaan secara lisan, untuk dijawab secara lisan juga, cirri utama dari interview adalah kontak langsung dengan tatap muka antara pencari informasi dengan sumber informasi”.

Analisis data penelitian kualitatif pada dasarnya sudah dilakukan sejak awal kegiatan penelitian sampai akhir penelitian. Dengan cara ini diharapkan terdapat konsistensi analisis data secara keseluruhan. Karena mengingat penelitian ini bersifat deskriptif, maka digunakan analisa data filosofis atau logika yaitu analisa induktif. 
Metode induktif adalah metode berpikir dengan mengambil kesimpulan dari data-data yang bersifat khusus. Sebagai mana yang telah dijelaskan oleh Sutrisno, yaitu: Berfikir induktif berangkat dari fakta-fakta yang khusus, peristiwa-peristiwa yang kongkrit, kemudian dari fakta-fakta atau peristiwa-peristiwa yang khusus, kongkrit itu ditarik generalisasi-generalisasi yang mempunyai sifat umum". (Sutrisno, 1986: 42)

Dalam penelitian ini digunakan metode induktif untuk menarik suatu kesimpulan terhadap hal-hal atau peristiwa-peristiwa dari data yang telah dikumpulkan melalui observasi, wawancara, dan dokumentasi, yang bisa digeneralisasikan (ditarik kearah kesimpulan umum), maka jelas metode induktif ini untuk menilai fakta-fakta empiris yang ditemukan lalu dicocokan dengan teori-teori yang ada.

\section{PEMBAHASAN}

Pemimpin merupakan satu-satunya orang yang bertugas untuk memandu,menuntun, membimbing dan memberi pengawasam yang efisien kepada karyawan secara langsung maupun tidak langsung. Peranan pemimpin umumnya bertujuan untuk meningkatkan kualitas prestasi kerja karyawan dalam suatu perusahaan.

Selain itu sebagai seorang pemimpin harus mampu bersikap adil dan mampu memberikan yang menjadi hak setiap karyawan yang bekerja di pt. djarum tanpa ada yang dikurangi maupun yang dihilangkan.

Kemampuan pemimpin dalam menilai kapasitas kerja pada setiap karyawan juga digunakan untuk pengembangan dan kemajuan toko khususnya dalam pencapaian target setiap bulan yang telah ditetapkan oleh perusahaan. Pemimpin juga melakukan pemantauan aktivitas dan kegiatan karyawan juga sangat mempengaruhi kualitas dan kinerja karyawan di pt djarum . Pemimpin akan memantau karyawan yang datang terlambat dan tidak tepat waktu, yang melalaikan dan mengabaikan pekerjaaan dan karyawan yang tidak bertanggung jawab.

Selain dari pemantauan sikap karyawan oleh manager dan supervisor, penilaian prestasi kerja juga dilakukan dengan cara membuat ranking karyawan setiap bulan, yang diambil dari total sales yang telah dicapai setiap karyawan. Karyawan yang memiliki pencapain total sales tertinggi dan melebihi target yang telah ditetapkan akan mendapatkan reward berupa uang bonus serta penambahan hari libur, begitu juga sebaliknya 3 karyawan pada posisi ranking terbawah mendapatkan punishment berupa pembayaran denda serta penambahan shift lembur. Dengan adanya penerapan kebijakan ini maka diharapkan mampu memotivasi karyawan untuk lebih semangat lagi dalam hal memberikan pelayanan yang excelent kepada customer serta dapat memberikan konstribusi sales yang tinggi sehingga toko mampu mencapai target toko yang telah ditetapkan perusahaan. 
TABEL EVALUASI KERJA KARYAWAN

\begin{tabular}{|c|c|c|c|c|c|c|}
\hline No. & $\begin{array}{c}\text { Nama } \\
\text { karyawan }\end{array}$ & $\begin{array}{c}\text { Efektifitas } \\
\text { dan } \\
\text { efisiensi } \\
\text { kerja }\end{array}$ & $\begin{array}{c}\text { Inisiatif } \\
\text { kerja }\end{array}$ & $\begin{array}{c}\text { Perilaku: } \\
\text { Disiplin } \\
\text { Tanggung } \\
\text { jawab }\end{array}$ & $\begin{array}{c}\text { Total sales } \\
\text { (\% pencapain } \\
\text { target) }\end{array}$ & $\begin{array}{l}\text { Total } \\
\text { Nilai }\end{array}$ \\
\hline 1 & & & & & & \\
\hline 2 & & & & & & \\
\hline 3 & & & & & & \\
\hline 4 & & & & & & \\
\hline 5 & & & & & & \\
\hline 6 & & & & & & \\
\hline 7 & & & & & & \\
\hline
\end{tabular}

TABEL RANKING KARYAWAN BERDASARKAN PENCAPAIAN SALES

\begin{tabular}{|c|c|c|c|c|}
\hline No & Nama & $\begin{array}{l}\text { Total Sales } \\
\quad \text { ( Juta ) }\end{array}$ & $\begin{array}{c}\text { \% Konstribusi } \\
\text { Omset }\end{array}$ & Keterangan \\
\hline 1 & $\mathbf{A}$ & 74 & $7,5 \%$ & $\begin{array}{c}\text { Insentif + } \\
\text { tambahan libur }\end{array}$ \\
\hline 2 & B & 69,5 & $7 \%$ & insentif \\
\hline 3 & $\mathrm{C}$ & & & \\
\hline 4 & D & & & \\
\hline 5 & $\mathbf{E}$ & & & \\
\hline 6 & $\mathbf{F}$ & & & \\
\hline 7 & $\mathbf{G}$ & & & \\
\hline 8 & H & & & \\
\hline 9 & I & & & \\
\hline 10 & $\mathbf{J}$ & & & \\
\hline 11 & $\mathbf{K}$ & & & \\
\hline 12 & $\mathbf{L}$ & 37 & $3,5 \%$ & Lembur \\
\hline 13 & $\mathbf{M}$ & 35 & $3 \%$ & $\begin{array}{l}\text { Denda + } \\
\text { Lembur }\end{array}$ \\
\hline 14 & $\mathbf{N}$ & 29 & $3 \%$ & $\begin{array}{l}\text { Denda + } \\
\text { Lembur }\end{array}$ \\
\hline
\end{tabular}




\section{KESIMPULAN}

Dari berbagai uraian di atas maka dapat disimpulkan bahwa :

Pemgambilan keputusan merupakan proses memilih sejumlah alternatif penting bagi pemimpin, karena proses pengambilan keputusan mempunyai peran penting dalam memotivasi kepemimpinan, komunikasi, koordinasi, dan perubahan perusahaan yang dilakukan oleh seorang pemimpin pada perusahaan yang dia pimpin. Pengambilan keputusan juga bisa dipandang sebagai proses memilih dari berbagai alternatif untuk memecahkan masalah dalam rangka pencapaian tujuan sebuah perusahaan.

Pengambilan keputusan yang efektif perlu dilakukan oleh seorang pemimpin dalam sebuah perusahaan. Dalam pengambilan keputusan seorang pemimpin harus memperhatikan berbagai aspek, misalnya perlu memperhatikan situasi dan kondisi, memperhatikan berbagai model, gaya, proses dan tidak kalah pentingnya perlu memperhatikan metode serta tahapantahapan secara sistematis. Sebab proses pengambilan keputusan selalu terkait dengan proses memilih dari berbagai alternatif.

Pengambilan keputusan yang efektif dapat berpengaruh terhadap peningkatan kualitas perusahaan yang dalam implementasinya bisa melalui variabel perantara yaitu meningkatnya kinerja, semangat, kreativitas dari karyawan-karyawan yang dipimpinnya. 


\section{DAFTAR PUSTAKA}

Alimudin, A. (2015). Strategi pengembangan minat wirausaha melalui proses pembelajaran. E-Jurnal Manajemen Kinerja, 1(1).

Alimudin, A., \& Sukoco, A. (2017). The Leadership Style Model That Builds Work Behavior Through Organizational Culture. JURNAL LENTERA: Kajian Keagamaan, Keilmuan Dan Teknologi, 3(2), 362-375.

Alimudin, A., \& Sasono, A. D. (2015). Peningkatan daya saing produk konveksi usaha kecil berbasis iptek di desa tri tunggal kecamatan babat lamongan. In Seminar Nasional Teknologi Terapan SV UGM.

Alimudin, A., \& Yoga, H. (2015). STRATEGI MENINGKATKAN LOYALITAS PELANGGAN PADA USAHA KECIL PRODUK MAKANAN RINGAN DI SURABAYA. Sustainable Competitive Advantage (SCA), 5(1).

Anzizhan, Syafaruddin. Sistem pengambilan keputusan pendidikan.Ebook.

Anonim. 2013. Pengertian, Tujuan, dan Manfaat Organisasi

(https://www.contohlengkap.com/2013/08/ diakses pada 23 Oktober 2016).

Didi Wahyu Sudirman. 2003. Pengambilan Keputusan sebagai Langkah Strategis Tugas Manajer. journal.uny.ac.id, 3(2): 93-101.

ItaLizawati dan A Kistyanto. 2014. Pengaruh Gaya Kepemimpinan Transformasional

Kreitner, Robert dan Kinicki, Angelo. 2005. Perilaku Organisasi. Jakarta: Salameba Empat Terhadap Efektivitas Organisasi Melalui Pengambilan Keputusan.JurnalMahasiswa Teknologi, 1 (6): 1606-1618.

Syiah Kuala. 2015. Pengambilan Keputusan Sekolah Melalui Manajemen Strategik Pada Sekolah Menengah Pertama Negeri 1 Bandar Baru. Jurnal Magister Administrasi Pendidikan, 3(3): 58-67.

Northouse, G. 2007. Leadership theory and practice. (3rd ed.) Thousand Oak, London, New Delhe, Sage Publications, Inc

Rebekka Rismayanti. 2016. Corporate Decision Making dalam Komunikasi Organisasi. Informasi Kajian Ilmu Komunikasi. 46 (1): 49-62. 